\title{
Diversity of apostome ciliates, Chromidina spp. (Oligohymenophorea, Opalinopsidae), parasites of cephalopods of the Mediterranean Sea
}

\author{
Dhikra Souidenne $^{1,2}$, Isabelle Florent ${ }^{1}$, Marc Dellinger ${ }^{1}$, Jean Lou Justine ${ }^{3}$, \\ Mohamed Salah Romdhane ${ }^{2}$, Hidetaka Furuya ${ }^{4}$, and Philippe Grellier ${ }^{1}$,* \\ ${ }^{1}$ UMR 7245 CNRS MCAM, Muséum National d'Histoire Naturelle, Sorbonne Universités, CP 52, 57 rue Cuvier, 75005 Paris, France \\ 2 UR03AGRO1 Ecosystèmes et Ressources Aquatiques, Institut National Agronomique de Tunisie, 43 avenue Charles Nicolle, \\ 1082 Tunis, Tunisia \\ 3 ISYEB, Institut de Systématique, Évolution, Biodiversité (UMR7205 CNRS, EPHE, MNHN, UPMC), Muséum National d'Histoire \\ Naturelle, Sorbonne Universités, CP 51, 55 rue Buffon, 75005 Paris, France \\ 4 Department of Biology, Graduate School of Science, Osaka University, 1-1 Machikaneyama, 560-0043 Toyonaka, Osaka, Japan
}

Received 16 March 2016, Accepted 3 August 2016, Published online 17 August 2016

\begin{abstract}
Chromidina spp. are enigmatic apostome ciliates (Oligohymenophorea, Opalinopsidae) that parasitise the renal and pancreatic appendages of cephalopods. Only four species have been described, among which only three have been formally named. No DNA sequence has been reported so far. To investigate Chromidina spp. diversity, we sampled cephalopods in the Mediterranean Sea off Tunis, Tunisia, and identified two distinct Chromidina spp. in two different host species: Loligo vulgaris and Sepia officinalis. From haematoxylin-stained slides, we described morphological traits for these parasitic species and compared them to previous descriptions. We also re-described the morphology of Chromidina elegans (Foettinger, 1881) from Chatton and Lwoff's original materials and designated a neohapantotype and paraneohapantotypes for this species. We describe a new species, Chromidina chattoni Souidenne, Florent and Grellier n. sp., found in L. vulgaris off Tunisia, and evidence for a probable novel species, found in $S$. officinalis off Tunisia, although this latter species presents similarities to some morphological stages previously described for Chromidina cortezi Hochberg, 1971. We amplified, for the first time, an 18S rDNA marker for these two Chromidina species. Phylogenetic analysis supports the association of Chromidina within apostome ciliates. Genetic distance analysis between 18S rDNA sequences of representative apostomes indicates Pseudocollinia as the most closely related genus to Chromidina.
\end{abstract}

Key words: Apostome, Ciliate, Cephalopods, Neohapantotype, Chromidina elegans, Chromidina chattoni $\mathrm{n}$. sp.

Résumé - Diversité des ciliés apostomes, Chromidina spp. (Oligohymenophorea, Opalinopsidae) parasites de céphalopodes en mer Méditerranée. Les Chromidina spp. sont des ciliés apostomes (Oligohymenophorea, Opalinopsidae) énigmatiques qui parasitent les sacs rénaux et pancréatiques des céphalopodes. Seules quatre espèces ont été décrites dont trois ont été formellement nommées. Aucune séquence d'ADN n'a été reportée à ce jour. Afin d'explorer la diversité des espèces du genre Chromidina, nous avons échantillonné des céphalopodes en mer Méditerranée, au large de Tunis en Tunisie, et avons identifié deux espèces distinctes de Chromidina spp. chez deux hôtes différents, Loligo vulgaris et Sepia officinalis. À partir de lames colorées à l'hématoxyline, nous avons analysé les traits morphologiques de ces parasites et les avons comparés aux descriptions antérieures. Nous avons également redécrit la morphologie de Chromidina elegans (Foettinger, 1881) à partir du matériel original de Chatton et Lwoff et avons désigné un néohapantotype et des paranéohapantotypes pour cette espèce. Nous

Dhikra Souidenne - urn:lsid:zoobank.org:author:B5B5ECCE-9F1D-4917-81DC-733D7DCEA774

Isabelle Florent - urn:1sid:zoobank.org:author:5DF07649-B2AF-4618-BDB4-83165AA1665C

Marc Dellinger - urn:1sid:zoobank.org:author:3F979C9C-D9B6-4E05-9375-2E06D8966C28

Jean Lou Justine - urn:1sid:zoobank.org:author:17643DCB-2C9D-4386-BB94-D2F04966B0E9

Mohamed Salah Romdhane - urn:1sid:zoobank.org:author:30F952A6-6168-42B8-B975-18B5144D394A

Hidetaka Furuya - urn:1sid:zoobank.org:author:97BD05EA-1C95-480D-85BD-FA49E7AE01BA

Philippe Grellier - urn:lsid:zoobank.org:author:A5DABAC3-1DF4-435C-A39B-6125814EAF06

*Corresponding author: grellier@mnhn.fr 
décrivons une nouvelle espèce, Chromidina chattoni Souidenne, Florent and Grellier n. sp., trouvée chez L. vulgaris en Tunisie, et signalons une espèce probablement nouvelle trouvée chez $S$. officinalis en Tunisie, bien que cette dernière présente des similitudes avec des stades morphologiques précédemment décrits pour Chromidina cortezi Hochberg, 1971. Nous avons amplifié, pour la première fois, le marqueur ADNr 18S pour ces deux espèces de Chromidina. L'analyse phylogénétique supporte l'association des Chromidina au sein des ciliés apostomes. L'analyse des distances génétiques de ce marqueur chez des apostomes représentatifs suggère que le genre Pseudocollinia est le plus proche du genre Chromidina.

\section{Introduction}

Species of Chromidina Gonder, 1905 [15] are enigmatic apostome ciliates being, after dicyemids, the most frequently encountered parasites inhabiting the reno-pancreatic appendages of cephalopods [18-20,30]. Initially in 1881, Foettinger observed infusoria parasites in Sepia elegans renal appendages. Recognising that these parasites were atypical protozoa, he erected the genus Benedenia [11], named after the embryologist Edouard van Beneden. In 1905, Gonder re-examined these parasites, highlighting their nuclear system organised as a network throughout the cell. Since this type of nuclear system arrangement was considered by Gonder as typical of chromidial systems, he changed the genus name from Benedenia to Chromidina [11]. Currently, 23 cephalopod species have been recorded as hosts of Chromidina spp., of which only three have been formally described: Chromidina elegans (Foettinger, 1881), C. coronata (Foettinger, 1881) and C. cortezi Hochberg, 1971. A fourth has been described morphologically but not named (Table 1) [25]. These ciliates infest mainly pelagic cephalopods, such as epi-meso pelagic squids, cuttlefishes and octopuses. Occasionally, they may be found in the kidneys of benthic hosts, if these hosts include a young nektonic stage during their development [13].

Chromidina spp. have a polymorphic dixenous life cycle, with two different budding processes which are monotomy and palintomy. The adult stage, the vermiform tropho-tomont, has a maximum body length varying from $400 \mu \mathrm{m}$ to $2,000 \mu \mathrm{m}[20]$. Some rare adult stages can have an accelerated growth process. Their size increases so quickly that their length can measure up to $5,000 \mu \mathrm{m}$. Given their unusual extended size, these adult stages are called hypertrophonts. The tropho-tomont is uniformly ciliated and has no cytostome [4]. It is attached through its anterior end to the host kidney tissues with its body bathing in the renal fluids, and feeds by nutriment absorption from host cells and fluids [25]. Division by monotomy produces a single long bud from the posterior end, the apotomite, which is morphologically similar to its parent and develops into a second generation of trophotomonts after detachment and colonisation of the host kidney. Division by palintomy produces smaller buds that form a typical chain of individuals attached to the tropho-tomont, which differentiate into tomites. Budding occurs only from the posterior end. The tomite is a small ciliate form with a unique ciliature and a cytostome [4]. When detached, it is believed that the tomite leaves the renal appendages to be released with passage of urine into the sea. This stage is presumed to encyst, as a phoront, and to infest an intermediate host [17, 18]. However, no intermediate host has been confirmed so far. Chatton and Lwoff [4] grouped Chromidina within the apostome ciliates even though their life cycle and their morphology show important differences from typical apostomes. The main argument for such an association is that Chromidina tomites share ciliature organisation similar to that of apostome tomites. Besides the reference work of Chatton and Lwoff [4], reports by Hochberg [17, 18, 20], and the recent description of a novel Chromidina sp. by Landers [25], little is known about this enigmatic genus and notably, no DNA sequence has been reported so far.

In the present study, we examined the Tunisian teuthofauna for infections by Chromidina. We report here the description of two Chromidina species and compare their morphological traits to those of previously described parasites. We provide, for the first time, Chromidina 18S rDNA sequences. In the course of this study, we also re-described Chromidina elegans and designated a neohapantotype and paraneohapantotypes from the Chatton and Lwoff original slide collection [4]. A phylogenetic analysis was performed to evaluate the association of Chromidina with apostomes within the Oligohymenophorea.

\section{Materials and methods}

\section{Host sampling and isolation of parasites}

Cephalopods were obtained from fishermen from the harbour of La Goulette, who collected them off Tunis, in the Mediterranean Sea $\left(36^{\circ} 49^{\prime} 9.11^{\prime \prime} \mathrm{N}, 10^{\circ} 18^{\prime} 22.49^{\prime \prime} \mathrm{E}\right)$, in January 2013 and January 2014, using traditional earthenware jugs as fishing tools [31]. In total, 5 individuals of Loligo vulgaris and 38 individuals of Sepia officinalis were collected. The cephalopod species identification was based on morphological features relying on cited identification keys [23] and species descriptions (Marine Species Identification portal, http://species-identification.org). The hosts were rapidly dissected and their renal appendages collected. Small pieces of these renal appendages were smeared on glass microscope slides, which were immediately fixed in Bouin's fluid for $24 \mathrm{~h}$ then stored in $70 \%$ ethanol. The smears were then stained in Ehrlich's Haematoxylin and counterstained in eosin, then mounted with Entellan (Merck, Rahway, New Jersey) [12]. In parallel, additional renal appendage pieces from the same cephalopod host were put in individual Petri dishes in sterile distilled water and observed with a stereomicroscope to collect Chromidina specimens with Pasteur pipettes. These parasites 
Table 1. Summary of morphological features of Chromidina species.

\begin{tabular}{|c|c|c|c|c|c|c|c|c|c|c|c|c|c|}
\hline Parasite & & Host & Local & alisation & Specimens and status & Aspect & Crown & Presence & Presence of & Presence & Number & $18 \mathrm{~S}$ & Reference \\
\hline Species & Type & $\begin{array}{c}\text { Other hosts } \\
\text { described }\end{array}$ & Type & Others & & & & & & & & & \\
\hline C. elegans & Sepia elegans & $\begin{array}{l}\text { Sepia orbignyana, } \\
\text { Illex coindetti, } \\
\text { Todarodes } \\
\text { sagittatus, Octopus } \\
\text { salutii }\end{array}$ & Naples, Italy & $\begin{array}{c}\text { Mediterranean } \\
\text { Sea, English } \\
\text { Channel and } \\
\text { Banyuls-sur-Mer, } \\
\text { France }\end{array}$ & $\begin{array}{c}\text { MNHN-IR-1970-9 } \\
\text { (neohapantotype) } \\
\text { MNHN-IR-1970-18 } \\
\text { to } 64 \\
\text { (paraneohapantotypes) }\end{array}$ & Club-like & No & ND & Yes & Yes & 14 & - & $\begin{array}{c}{[4,11,} \\
15], \text { this } \\
\text { study }\end{array}$ \\
\hline C. coronata & $\begin{array}{l}\text { Octopus } \\
\text { vulgaris }\end{array}$ & $\begin{array}{c}\text { Eledone cirrhosa, } \\
\text { Sepiola rondeleti, } \\
\text { Scaeurgus } \\
\text { unicirrhus, } \\
\text { Illex coindetti }\end{array}$ & Naples, Italy & $\begin{array}{l}\text { Mediterranean } \\
\text { Sea and English } \\
\text { Channel }\end{array}$ & & Claviform & Yes & ND & ND & ND & ND & - & {$[11,20]$} \\
\hline C. cortezi & $\begin{array}{l}\text { Pterygioteuthis } \\
\text { giardi }\end{array}$ & - & $\begin{array}{c}\text { Gulf of } \\
\text { California }\end{array}$ & Gulf of Mexico & & Pointed & No & Yes & Yes & Yes & 12 & & [17] \\
\hline $\begin{array}{l}\text { Chromidina } \\
\text { sp. }\end{array}$ & Illex coindetti & - & Gulf of Mexico & - & & Bulbous & No & Yes & ND & Yes & 12 & & {$[25]$} \\
\hline C. chattoni & Loligo vulgaris & - & $\begin{array}{l}\text { Tunis, Tunisia, } \\
\text { Mediterranean } \\
\text { Sea }\end{array}$ & - & $\begin{array}{c}\text { MNHN-IR-2016- } \\
326 \text { (hapantotype) } \\
\text { MNHN-IR-2016- } \\
327-341 \\
\text { (parahapantotypes) }\end{array}$ & Globulous & s No & ND & ND & Yes & 13 & $\begin{array}{l}\text { LT546660 } \\
\text { LT546661 } \\
\text { LT546662 }\end{array}$ & $\begin{array}{l}\text { This } \\
\text { study }\end{array}$ \\
\hline $\begin{array}{l}\text { Chromidina } \\
\text { sp. S50 }\end{array}$ & Sepia officinalis & - & $\begin{array}{c}\text { Tunis, Tunisia, } \\
\text { Mediterranean } \\
\text { Sea }\end{array}$ & - & $\begin{array}{l}\text { MNHN-IR-2016- } \\
108 \text { (voucher) }\end{array}$ & Conical & No & ND & ND & ND & - & LT546663 & $\begin{array}{l}\text { This } \\
\text { study }\end{array}$ \\
\hline
\end{tabular}

ND: not described. 
were then transferred to new Petri dishes to be washed several times, in order to eliminate the host tissue possibly remaining attached to the parasites. Washed parasites were then transferred, one by one, to sterile Eppendorf tubes filled with $70 \%$ ethanol and were stored at $4{ }^{\circ} \mathrm{C}$ until use for DNA isolation.

\section{Morphological studies}

Smears were observed by light microscope. Images were recorded using a Nikon DXM $1200 \mathrm{C}$ camera and processed using ImageJ software (http://imagej.nih.gov/ij/). Measurements were made with the aid of a micrometric slide by using the ImageJ Set Scale module. Target Chromidina spp. were observed on slides prepared from positive hosts; specifically, three infected L. vulgaris individuals (C21, C22 and C23) and one infected $S$. officinalis individual (S50). Smears of these specimens were deposited in the Protist collection of the Muséum National d'Histoire Naturelle, Paris, France (www.mnhn.fr/fr/collections/ensembles-collections/invertebresmarins/protistes). The morphologies of these Chromidina spp. specimens were compared to descriptions from the literature and to the original Chatton and Lwoff's smeared slides used to describe Chromidina elegans [4], which are deposited in the Protist collection of the Muséum National d'Histoire Naturelle. Since no type slide related to Foettinger's work [11] could be localised, we undertook to re-describe this species to which we associated a neohapantotype and paraneohapantotypes.

\section{Molecular studies}

DNA extractions were performed using Chelex ${ }^{\mathrm{TM}}$ (Biorad), following the methodology described in reference [9]. The 18S rDNA loci of Chromidina were amplified by using the universal primer pair MDP4 (forward, 5'-CTGGTTGATCCTGCCAG-3', [1]) and MDP3 (reverse, 5'-GACGGGCGGTGTGTAC-3', [26]), and two Chromidinaspecific primers designed in the course of this study: FurF (forward, 5'-GCAGGCGCGTAAATTA-3') and FurR (reverse, $5^{\prime}$-CACTCGAAATCGGTAGCA-3 ${ }^{\prime}$ ). The HOT FIREPol ${ }^{\circledR}$ DNA Polymerase enzyme was used as recommended by the supplier. Briefly, following an initial denaturation period of $12 \mathrm{~min}$ at $94{ }^{\circ} \mathrm{C}, 35$ cycles of denaturation for $30 \mathrm{~s}$ at $94{ }^{\circ} \mathrm{C}$, annealing for $1 \mathrm{~min}$ at $50{ }^{\circ} \mathrm{C}$, and elongation for 2 min at $72{ }^{\circ} \mathrm{C}$, were performed, and the PCR was terminated by a final elongation for $7 \mathrm{~min}$ at $72{ }^{\circ} \mathrm{C}$. The quality of the yielded amplicons (single band, proper size) was validated after electrophoresis in $1 \%$ Agarose $^{\mathrm{TM}}$ gels in $0.5 \times$ TAE buffer, in the presence of $0.5 \mu \mathrm{g} / \mathrm{mL}$ ethidium bromide and UV illumination. The positive amplicons were either sequenced directly or purified using Illustra ${ }^{\mathrm{TM}} \mathrm{GFX}^{\mathrm{TM}}$ PCR DNA and Gel Band Purification kit (GE Healthcare, France) to be cloned into $\mathrm{pGEM}^{\mathrm{R}}$-T Easy vector (Promega, France) following the supplier's recommendations. Positive clones were selected by PCR using universal T7 (5'-TAGTTATTGCTCAGCGGTGG$\left.3^{\prime}\right)$ and Sp6 (5'-ATTTAGGTGACACTATAG-3') primers flanking the $\mathrm{pGEM}^{\mathrm{R}}-\mathrm{T}$ Easy vector cloning site. DNA sequencing was performed by the Sanger method on PCR-amplified fragments, using appropriate primers (T7, Sp6, MDP4, MDP3, FurF, FurR) (Beckman Coulter Genomics, Takeley, UK). Raw chromatograms were analysed using the BioEdit 7.1.3.0 program [16] and loci were assembled using the MEGA 6.06 package [33]. The new 18S rDNA sequences (1516-1541 pb in length), obtained from Chromidina used for the morphological identification, were deposited in the EMBL database (LT46660-LT46663).

\section{Genetic distance between apostome species}

18S rDNA sequences from the four Chromidina specimens isolated from the infected hosts and 10 18S rDNA sequences representative of each Apostomatia species, retrieved from the EMBL or GenBank databases, were aligned using the online version of MAFFT, version 7 (http://mafft.cbrc.jp/ alignment/server/; [24]), using the secondary structure of RNA (Q-INS-I option). Evolutionary distances between the sequences were computed pairwise using p-distances and uniform rate analyses in MEGA 6.06 [33]. All ambiguous positions were removed for each sequence pair and there were a total of 1,477 positions in the final dataset. The numbers of base differences per site between sequences were expressed as percentages.

\section{Maximum likelihood and Bayesian rooted trees for Ciliophora}

18S rDNA sequences from the four Chromidina specimens, and 25 sequences of representatives of Ciliophora and from the Dinoflagellate Biecheleriopsis adriatica (HG792067) taken as the outgroup, were aligned using the online version of MAFFT, version 7 (http://mafft.cbrc.jp/ alignment/server/; [24]), using the secondary structure of RNA (Q-INS-I option), and the alignment was filtered out using the online version of GBlock [2]. GBlock settings were set to allow moderately strict flanking positions (Maximum number of contiguous non-conserved positions: 8; minimum length of a block: 10; no gap position allowed), yielding a confident alignment of 1,157 positions. A general time-reversible (GTR) substitution model with gamma-distributed rate variation across sites was suggested by JModeltest V2.1.3 as the best-fit model for this alignment [8]. Accordingly, a Bayesian phylogenetic tree was constructed with MrBayes v.3.2.3 [32], using lset $n s t=6$ rates $=$ Invgamma Ngammacat $=4$ parameters. Four simultaneous Monte Carlo Markov chains were run from random trees for a total of $5,000,000$ generations in two parallel runs. A tree was sampled every 1,000 generations and $25 \%$ of the trees were discarded as "burn-in". A consensus tree was constructed from the postburn-in trees using FigTree v1.3.1, and posterior probabilities were calculated in MrBayes. In parallel, Maximum Likelihood analyses were performed using the same alignment and the GTR+G+I model, with MEGA 6.06 [33]. Bootstraps were estimated from 1,000 replicates.

Phylum: Ciliophora Doflein, 1901.

Subphylum: Intramacronucleata Lynn, 1996. 
Class: Oligohymenophorea de Puytorac et al., 1974. Subclass: Apostomatia Chatton \& Lwoff, 1928.

Order: Astomatophorida Jankowksi, 1966.

Family: Opalinopsidae Hartog, 1906.

Genus: Chromidina Gonder, 1905.

\section{Chromidina elegans (Foettinger, 1881) Gonder, 1905 (Fig. 1)}

Synonym: Benedenia elegans Foettinger, 1881.

Host: Sepia elegans d'Orbigny, 1825.

Infection site: Renal appendages.

Other reported hosts: Sepia orbignyana Ferussac, 1826, Illex coindetti Vérany, 1837 in the Mediterranean Sea and English Channel; Todarodes sagittatus Lamarck, 1798 and Octopus salutii Vérany, 1839 in the Mediterranean Sea [4, 17, 29]. Wermel [34] observed C. elegans-like species in Russia on Loligo sp., and Jepps [22] and Clarke [6] in Spirula spirula Linnaeus, 1758 in the Atlantic Ocean.

Type material: Neohapantotype catalogued under No. MNHN-IR-1970-9 and paraneohapantotypes catalogued under Nos. MNHN-IR-1970-18 to 64 from Chatton and Lwoff's work on C. elegans [4], deposited in the Protist Collection of the Muséum National d'Histoire Naturelle.

Type locality: Banyuls-sur-Mer, France $\left(42^{\circ} 29^{\prime} 01^{\prime \prime} \mathrm{N}\right.$, $3^{\circ} 07^{\prime} 44^{\prime \prime}$ E) [4].

Other reported localities: Initially described from Naples, Italy, by Foettinger [11].

Prevalence: No information available.

Chromidina elegans was initially described by Foettinger in 1881 but under the genus Benedenia Foettinger, 1881 and not Chromidina [11]. In his pioneering work, Foettinger did not designate a type species despite detailed descriptions of $C$. elegans (formerly B. elegans). We were unable to trace the existence of a corresponding type- or hapantotype-slide in the literature, and the Ciliate Resource Archive database (http://www.uoguelph.ca/ ciliates/) indicates that these are absent for this genus. Later, Chatton and Lwoff provided a detailed description of $C$. elegans and clearly designated in their monograph this species as the type species for the genus Chromidina, but without indicating any type- or hapantotypeslide [4]. However, Chatton's slide collection was deposited by the French National Centre for Scientific Research in the Protist Collection of the Muséum National d'Histoire Naturelle, Paris, France, in the 1970s. We therefore used Chatton's C. elegans slides to re-examine this parasite. Particular attention was paid to the tropho-tomont and tomite stages found in the renal appendages of Sepia elegans, as these stages were considered representative of the species [11] by Chatton and Lwoff in 1935 [4]. This work enabled us to formally designate a neohapantotype and paraneohapantotypes for the C. elegans species, from this slide collection.

Materials examined: Forty-eight slides corresponding to smears prepared by Chatton and Lwoff from renal appendages of Sepia elegans collected in Banyuls-sur-Mer, France [4], were deposited in the Protist Collection of the Muséum National d'Histoire Naturelle.
Redescription: The species description is based on the morphology of the tropho-tomont stage attached to the renal and pancreatic excretory epithelium, as previously proposed by Foettinger [11] then by Chatton and Lwoff [4]. Trophotomont body: thin, elongated, vermiform, length $30-1,400 \mu \mathrm{m}$, body average width $21.1 \pm 3.3 \mu \mathrm{m}(N=132)$. Subpellicular macronucleus stained by haematoxylin, open and reticulated network of chromatin throughout the whole body (Fig. 1B).

Anterior end: Inflated, club-like (Figs. 1B-1D), terminated by a distinguishable apical papillum (Figs. 1C and 1D), attaching the tropho-tomonts to the renal tissues (Fig. 1A). Largest width of $53.2 \pm 11.8 \mu \mathrm{m}(N=120)$.

Ciliature: Tropho-tomonts entirely covered by cilia (Fig. 1D); ciliature consisting of 14 kineties (Fig. 1E) originating from the apex, dextrally spiralled, directed anteroposteriorly continuously with no break (Fig. 1G).

Posterior end: Division by palintomy (Fig. 1F) with chains of primary segments (Fig. 1H), generating up to 24 protomites by fission (Fig. 1I). Protomites with condensed chromatin network (Fig. 1F). Tomites with ellipsoidal form (Fig. 1J) and size of $27.2 \pm 1.7 \mu \mathrm{m}$ by $17.8 \pm 2.4 \mu \mathrm{m} \quad(N=30)$. Presence of apotomites not confirmed.

\section{Chromidina chattoni Souidenne, Florent and Grellier n. sp. (Fig. 2)}

urn:1sid:zoobank.org:act:A533901D-8325-4412-AF74C63341DB03C7

Type host: Loligo vulgaris Lamarck, 1798.

Infection site: Renal appendages.

Type material: Hapantotype catalogued under No. MNHNIR-2016-326 and parahapantotypes catalogued under Nos. MNHN-IR-MNHN-2016-327 to 341, haematoxylin-stained smears from the three infected L. vulgaris C21, C22 and C23, deposited in the Protist Collection of the Muséum National d'Histoire Naturelle, Paris, France.

Etymology: The species name was chosen in memory of the French biologist Edouard Chatton for his extensive and remarkable studies on apostomes.

Type locality: Off Tunis, Tunisia, Mediterranean Sea (36 $\left.49^{\prime} 9.11^{\prime \prime} \mathrm{N}, 10^{\circ} 18^{\prime} 22.49^{\prime \prime} \mathrm{E}\right)$.

DNA sequence: Partial sequences of $18 \mathrm{~S}$ rDNA amplified from parasites isolated from the three infected $L$. vulgaris hosts deposited in the EMBL/GenBank/DDBJ database (Accession numbers: LT546660 (C21), LT546661 (C22) and LT546662 (C23)).

Prevalence: Sixty percent (three out of five specimens of L. vulgaris examined from off Tunis, Tunisia).

Authorship: Note that the authors of the new taxon are different from the authors of this paper, Article 50.1 and Recommendation 50A of the International Code of Zoological Nomenclature [21].

Description: Based on the morphology of the tropho-tomont stage. Parasite morphology identical on smears prepared from the three infected L. vulgaris hosts. Free swimming trophotomonts observed in renal fluids. Tropho-tomont body: Elongated and thin vermiform shape. Body width constant 

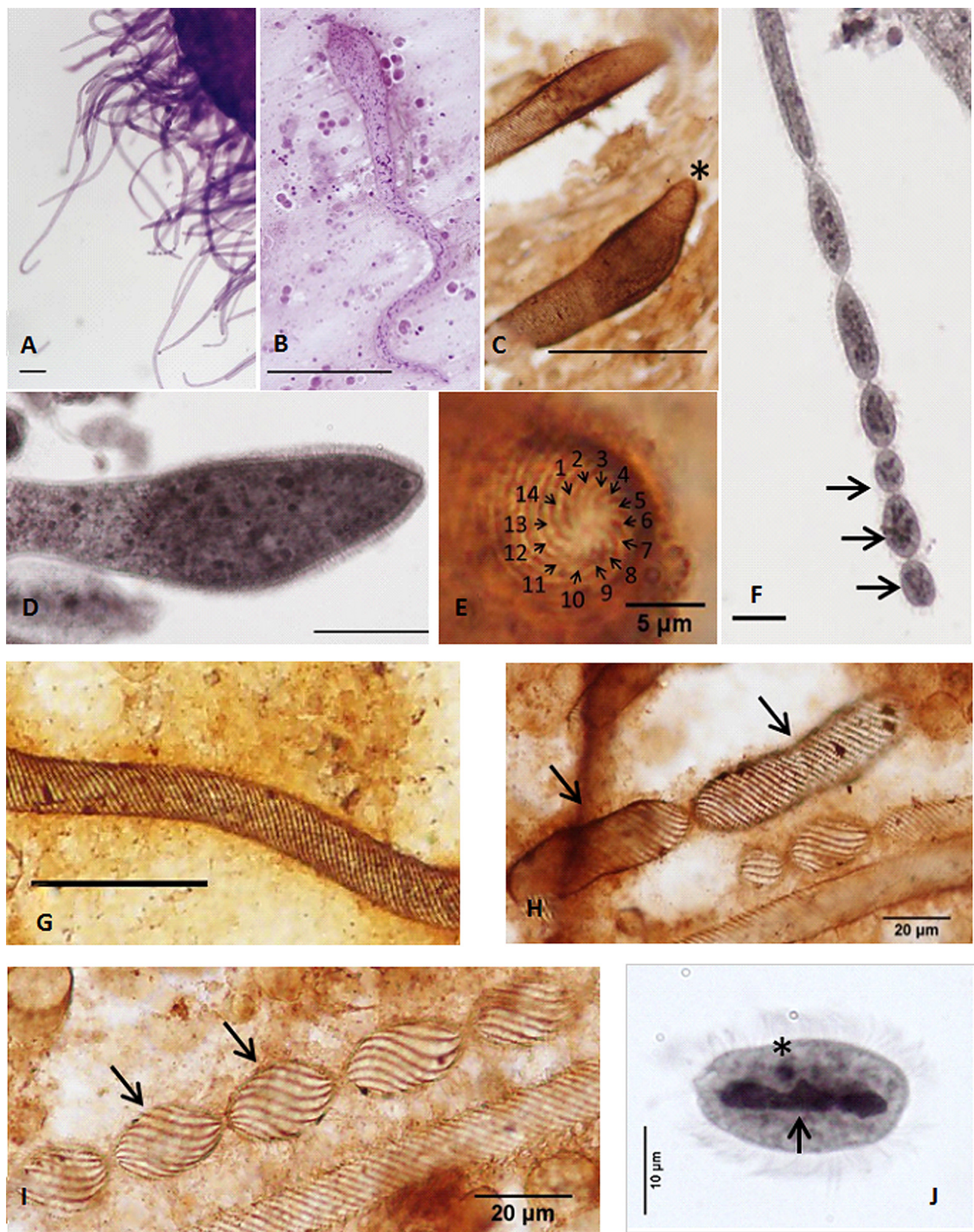

Figure 1. Chromidina elegans (Foettinger, 1881) Gonder, 1905: morphology. (A) General view of infected renal sac. Parasites are attached to the renal tissues by their anterior end with their cell body hanging free in the renal coelom. (B) Tropho-tomont. (C, D) Club-like and inflated anterior ends of tropho-tomonts (*: apical papillum). (E) Apical ciliature consisting of 14 kineties that extend continuously through the entire cell body. (F) Palintomy (arrow: protomites with condensed chromatin). (G) Cell body ciliature. (H) First generation of protomites (arrow: fission plan). (I) Chain of second generation of protomites (arrows). (J) Free tomite (*: micronucleus, arrow: macronucleus). (A, B) Haematoxylin staining. (C, E, G-I) Chatton's silver impregnation. (D, F, J) Osmium staining. Unless otherwise indicated, bar $=100 \mu \mathrm{m}$. (A-J) Neohapantotype and paraneohapantotypes. 

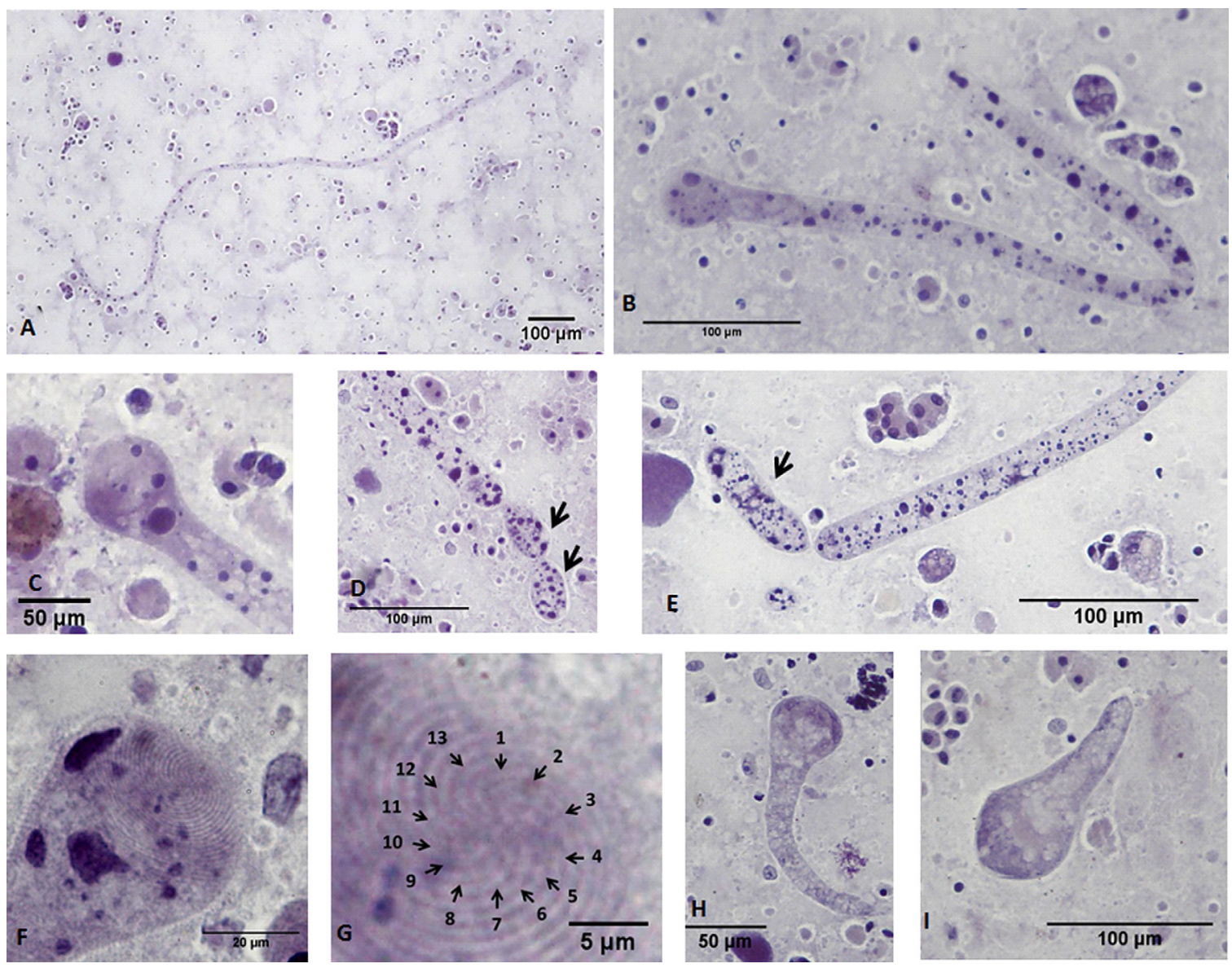

Figure 2. Chromidina chattoni Souidenne, Florent and Grellier n. sp.: morphology. (A, B) General views of tropho-tomonts. (C) Bulb-like head of tropho-tomont. (D, E) Palintomy with first generation of protomites (E) and second generation of protomites (D), arrows: protomites. (F) Bulb-like head of tropho-tomont. Note the presence of large and darkly-stained spots of chromatin associated with the head. (G) Ciliature consisting of 13 kineties (zoom of Fig. 2F). (H-I) Small forms of tropho-tomonts. Images were obtained from smears stained with haematoxylin. (A-I) Hapantotype and parahapantotypes.

along body length (mean $=19.5 \pm 3.7 \mu \mathrm{m}, N=60)$. Cytoplasm filled by darkly-stained islands of chromatin. Small trophotomonts weakly stained by haematoxylin, no clear network or spots of chromatin observed (Figs. 2H and 2I), suggesting degenerative forms rather than apotomite forms. Haematoxylin stain of tropho-tomonts revealing typical reticulated macronucleus of Chromidina [4], spreading throughout the entire cell body (Figs. 2B and 2E).

Anterior end (Fig. 2A): globular with regular width (mean $=40.8 \pm 4.7 \mu \mathrm{m}, N=52$ ). Typical bulb-like anterior end (Figs. 2A, 2B, 2C, 2F), but heterogeneous in length of $80-1,890 \mu \mathrm{m} \quad($ mean $=657 \pm 486 \mu \mathrm{m}, N=33)$. No distinguishable apical papillum observed. One to two large and darkly-stained spots of chromatin often associated with the bulb-like anterior end (Figs. 2B, 2C, 2F).

Ciliature: Consisting of 13 dextrally-spiralled kineties originating from the apex (Fig. 2G) and continuing uninterrupted on the entire cell body.

Posterior end: With typical Chromidina division segments that could generate either apotomites by monotony division or tomites by palintomy division (Figs. 2D and 2E).
Diagnosis: The C. chattoni n. sp. tropho-tomont has 13 kineties, which distinguishes it from other reported Chromidina species: 12 kineties for C. cortezi and the Chromidina sp. isolated from Illex coindetti in the Gulf of Mexico, and 14 for C. elegans [4] (Fig. 1E, Table 1). C. coronata has an unreported number of kineties but significantly differs from the other species by its bulbous anterior end covered by discernible superposed rows of dense and elongated cilia, presenting a crown-like aspect, which is the main identification feature for $C$. coronata (presence of a crown of cilia) $[11,17]$. In addition, $C$. chattoni $n$. sp. differs from C. elegans by a bulb-like anterior end (Figs. 2B, 2C, $2 \mathrm{~F})$ versus an inflated club-like anterior end with a distinguishable apical papillum (Figs. 1C and 1D; [4]), and a narrower head $(40.7 \pm 4.7 \mu \mathrm{m}$ versus $53.2 \pm 11.8 \mu \mathrm{m}$, respectively). C. cortezi was described with a rounded anterior end with widths ranging from 22 to $48 \mu \mathrm{m}$ [17].

C. chattoni $\mathrm{n}$. sp. has been observed in $L$. vulgaris off Tunis which differs from C. coronata that has been observed in Octopus vulgaris, Sepiola rondeleti, Illex coindetti, Eledone cirrhosa and Scaeurgus unicirrhus, in the Mediterranean Sea 

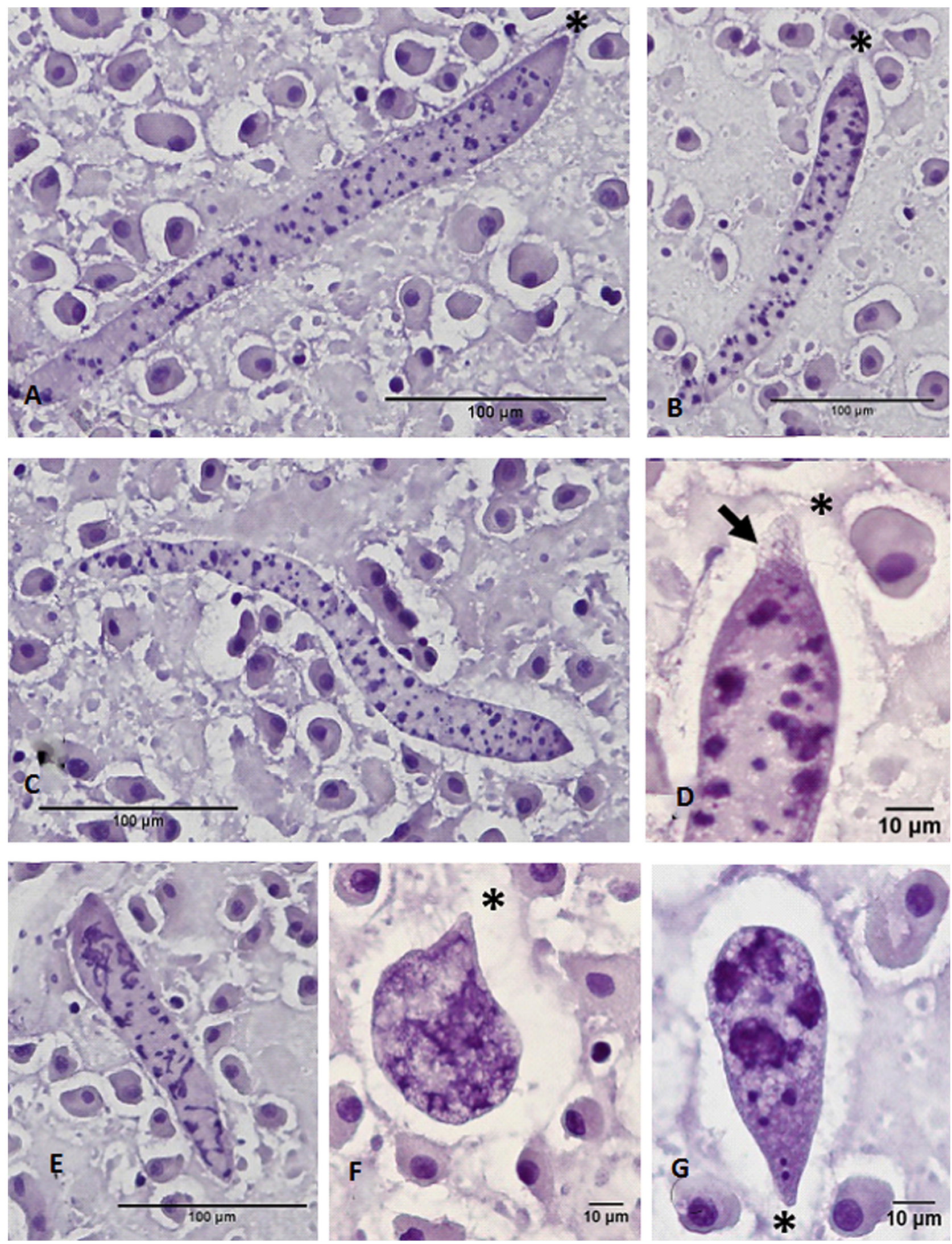

Figure 3. Chromidina sp. S50: morphology. (A-C, E) Tropho-tomonts: anterior end has a conical shape terminated by an apical papillum. (D) Enlargement of Figure 3B showing the apical papillum and the ciliature consisting of spiralled kineties originating from at the apex (arrow). (F, G) Degenerative-like or cyst-like forms. *: apical papillum. 
Table 2. Genetic distances (\%) between sequences of representative Apostomatia.

\begin{tabular}{|c|c|c|c|c|c|c|c|c|c|c|c|c|c|}
\hline & 1 & 2 & 3 & 4 & 5 & 6 & 7 & 8 & 9 & 10 & 11 & 12 & 13 \\
\hline \multicolumn{14}{|l|}{1 Chromidina chattoni LT546660 (C21) } \\
\hline 2 Chromidina chattoni LT546661 (C22) & 0.00 & & & & & & & & & & & & \\
\hline 3 Chromidina chattoni LT546662 (C23) & 0.07 & 0.07 & & & & & & & & & & & \\
\hline 4 Chromidina sp. S50 LT546663 (S50) & 0.20 & 0.20 & 0.14 & & & & & & & & & & \\
\hline 5 Pseudocollinia brintoni HQ591470 & 3.99 & 3.99 & 3.93 & 4.06 & & & & & & & & & \\
\hline 6 Pseudocollinia similis HQ591485 & 4.06 & 4.06 & 3.99 & 4.13 & 0.34 & & & & & & & & \\
\hline 7 Pseudocollinia beringensis HQ591476 & 4.13 & 4.13 & 4.06 & 4.20 & 0.27 & 0.07 & & & & & & & \\
\hline 8 Pseudocollinia oregonensis HQ591473 & 4.13 & 4.13 & 4.06 & 4.20 & 0.34 & 0.47 & 0.47 & & & & & & \\
\hline 9 Fusiforma themisticola KF516511 & 4.81 & 4.81 & 4.74 & 4.74 & 1.90 & 1.83 & 1.90 & 2.03 & & & & & \\
\hline 10 Gymnodinioides pitelkae EU503534 & 5.96 & 5.96 & 5.96 & 6.09 & 4.13 & 4.27 & 4.33 & 4.13 & 4.33 & & & & \\
\hline 11 Hyalophysa lwoffi EU503538 & 6.09 & 6.09 & 6.16 & 6.30 & 4.54 & 4.47 & 4.54 & 4.47 & 4.54 & 3.45 & & & \\
\hline 12 Vampyrophrya pelagica EU503539 & 6.09 & 6.09 & 6.03 & 6.16 & 4.67 & 4.67 & 4.67 & 4.40 & 4.60 & 3.32 & 2.44 & & \\
\hline 13 Hyalophysa chattoni EU503536 & 6.23 & 6.23 & 6.16 & 6.16 & 5.15 & 5.15 & 5.21 & 5.01 & 5.21 & 4.13 & 1.76 & 2.57 & \\
\hline 14 Gymnodinioides sp. EU503535 & 6.36 & 6.36 & 6.36 & 6.50 & 4.40 & 4.54 & 4.54 & 4.27 & 4.20 & 3.05 & 2.17 & 1.35 & 2.78 \\
\hline
\end{tabular}

The numbers of base differences per site between sequences are shown as percentages. The analysis involved 14 nucleotide sequences. All ambiguous positions were removed for each sequence pair. There were a total of 1,477 positions in the final dataset.

and English Channel [4, 7, 10, 20], C. cortezi that has been observed in Pterygioteuthis giardi in the Gulfs of California and Mexico by Hochberg [17, 20], and Chromidina sp. described by Landers [25], that has been isolated from Illex coindetti in the Gulf of Mexico.

\section{Chromidina sp. S50 from Sepia officinalis}

(Fig. 3)

Host: Sepia officinalis Linnaeus, 1758.

Infection site: Renal appendages.

Material: Haematoxylin-stained smears from the infected S. officinalis S50, deposited in the Protist Collection of the Muséum National d'Histoire Naturelle, under No. MNHNIR-2016-108.

Locality: Off Tunis, Tunisia, Mediterranean Sea (36 $\left.49^{\circ} 9.11^{\prime \prime} \mathrm{N}, 10^{\circ} 18^{\prime} 22.49^{\prime \prime} \mathrm{E}\right)$.

DNA sequence: Partial sequences of $18 \mathrm{~S}$ rDNA amplified from parasites isolated from $S$. officinalis host S50 deposited in the EMBL/GenBank/DDBJ database (Accession number LT546663).

Prevalence: $2.6 \%$ (one out of 38 specimens of $S$. officinalis examined from off Tunis, Tunisia).

Description: Tropho-tomonts from only one $S$. officinalis out of 38 specimens examined; infection at low level; host co-infected by the dicyemid Pseudicyema truncatum (data not shown).

Tropho-tomonts: Vermiform (Fig. 3A), length of 99.6-481.1 $\mu \mathrm{m}($ mean $=259.1 \pm 93.0 \mu \mathrm{m}, N=38)$, average body width of $23.4 \pm 4.9 \mu \mathrm{m}(N=117)$. Smallest trophotomonts with stockier and wider body (Fig. 3E). Small and rounded forms also observed, suggesting either degenerative forms or encystment process (Figs. 3F and 3G). Cytoplasm filled by darkly-stained islands of chromatin. Typical reticulated macronucleus of Chromidina spp. revealed by haematoxylin stain [4], spreading throughout the entire cell body.

Anterior end: Majority of parasites with conical shape terminated by a pronounced apical papillum attaching the parasite to the renal epithelium; width of the anterior end similar to that of the body (Figs. 3A-3E). Slight inflation of the head observed in a few parasites.

Ciliature: Consisting of dextrally-spiralled kineties originating from the apex and continuing on the cell body (Fig. 3D). Number of kineties not determined due to unfavourable positioning of tropho-tomonts on smears. Posterior end: long tropho-tomonts with narrower posterior end than anterior part (Figs. 3A and 3C). No division (monotomy or palintomy) observed.

Remarks: The absence of dividing stages and the impossibility of determining the number of kineties limit the comparison with the other Chromidina species. The absence of a crown of cilia differentiates it from $C$. coronata and this type of tropho-tomont morphology with a conical head was not observed for C. elegans. Hochberg [17, 20] described apotomites of $C$. cortezi with similar morphology on the renal appendages of the squid Pterigioteuthis giardi fished in the Gulfs of California and Mexico. Apotomites are large single buds produced by a monotonic process from trophotomonts. When detached, they differentiate into a second generation of tropho-tomonts that colonise the renal appendages. It is suggested that stress conditions such as a shortage of nutrients or of essential metabolites might result in the production of apotomites instead of tomites [17]. The presence of degenerative or cyst-like forms (Figs. 3F and 3G) in our preparations supports such stress conditions. Furthermore, co-infection with dicyemids indicates that the infection by this Chromidina sp. in S. officinalis S50 reaches its final stage. The Chromidina sp. population is progressively replaced by dicyemids, competing for the same ecological habitat, the renal appendages, when the host changes from a pelagic to a benthic life cycle [13]. Pterigioteuthis giardi was originally described from the Mediterranean Sea but is now known to be nearly cosmopolitan [17]. Whether the Chromidina sp. observed in our preparations corresponds to $C$. cortezi needs to be clarified and requires further investigation. In any case, this is the first description of a Chromidina sp. infecting Sepia officinalis. 


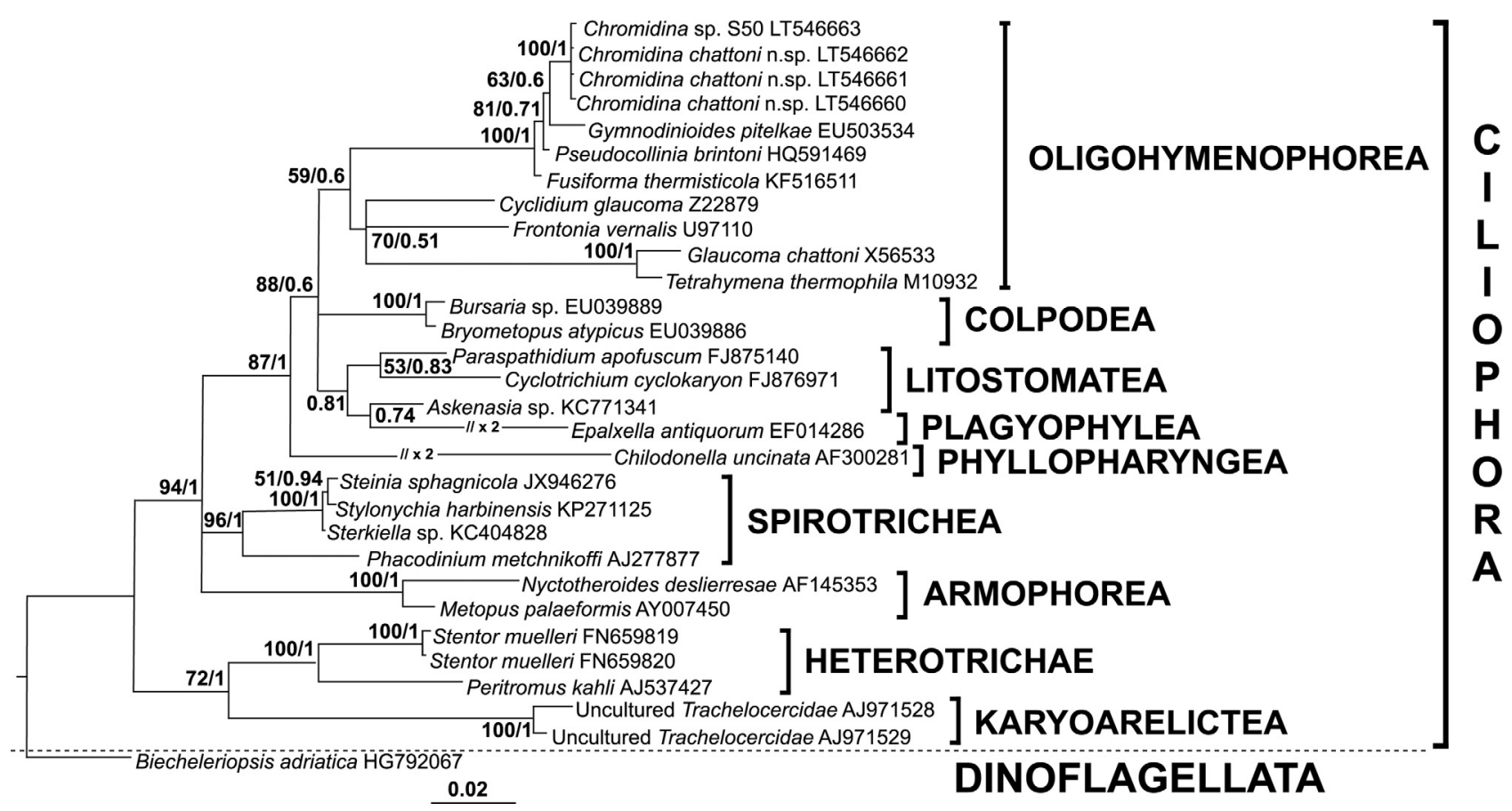

Figure 4. Phylogenetic position of Chromidina spp. within Ciliophora. This phylogenetic tree, rooted on a dinoflagellate rDNA sequence, was inferred from 30 small subunit (SSU) 18S rDNA sequences corresponding to the four Chromidina specimens identified in this study, 25 representatives of the major classes of the phylum Ciliophora, and one Dinoflagellata sequence taken as the outgroup. There were a total of 1,157 positions in the final dataset. Both the Maximum Likelihood (ML) method and Bayesian inferences, based on the general timereversible $+\mathrm{G}+\mathrm{I}$ model [28], were conducted and yielded similar topologies; the currently presented topology was obtained by the Bayesian inference. The tree is drawn to scale, with branch lengths measured in number of substitutions per site. Some branches were shortened by multiples of the length of substitutions/site scale bar (Plagyophylea, Phyllopharyngea). Numbers at the branches denote ML bootstrap percentage, from 1,000 resampling (first value) and Bayesian posterior probabilities (second value).

Table 1 summarises the specific characters of each Chromidina sp. described to date including Chromidina chattoni n. sp. from L. vulgaris and Chromidina sp. S50 from S. officinalis, both identified in the current study.

\section{Phylogenetic analysis}

Positive PCRs were obtained for each of the four Chromidina specimens collected from the infected cephalopod hosts, using universal and specific primers designed to amplify a portion of the Chromidina $18 \mathrm{~S}$ rDNA locus. Gene sequencing and assemblage enabled us to determine, for the first time, the partial 18S rDNA sequences for these parasite ciliates. Blast analyses revealed that the highest homology scores were obtained with known Apostomatia 18S rDNA sequences, in particular with species belonging to the genus Pseudocollinia $[14,27]$. A multiple alignment was built using these four Chromidina spp. sequences and a representative selection of Apostomatia to compute evolutionary distances (Table 2). Bayesian and Maximum Likelihood phylogenetic trees were also constructed using a selection of species belonging to several Ciliophora classes (Fig. 4).

The three sequences obtained for Chromidina species infecting $L$. vulgaris hosts were highly similar to each other and very close to the sequence obtained for the Chromidina sp. S50 infecting $S$. officinalis, with a genetic divergence of less than $0.2 \%$ (Table 2). The closest relatives of these Chromidina sp. sequences were those of Pseudocollinia brintoni (e.g. HQ591470, [14]), Pseudocollinia similis (e.g. HQ591485, [27]) Pseudocollinia beringensis (e.g. HQ591476, [27]) and Pseudocollinia oregonensis (e.g. HQ591473, [27]) with a genetic divergence of 3.9-4.2\%, then Fusiforma themisticola (KF516511, [3]) with a genetic divergence of 4.7-4.8\%. Gymnodinioides pitelkae (EU503534, [5]), Hyalophysa lwoffi (EU503538, [5]) and Vampyrophrya pelagica (EU503539, [5]), and Hyalophysa chattoni (e.g. EU503536.1, [5]) were found with a genetic divergence of 5.9-6.2\% and Gymnodinioides sp. (EU503535.1, [5]) of $\sim 6.4 \%$ (Table 2 ). These values reveal the rather low divergence between these species, for this molecular marker, as previously observed by Lynn for other Apostomatia [27]. Pseudocollinia spp., parasitoid apostomes of krill, currently appear the species most closely related to Chromidina spp. The phylogenetic analysis using a dinoflagellate sequence as an outgroup revealed that, within the Ciliophora phylum, these Chromidina spp. sequences remained grouped with the Apostomatia (Chromidina, Gymnodinioides, Pseudocollinia, Fusiforma) within the Oligohymenophorea class, with strong bootstrap values (Maximum Likelihood analysis) and posterior probability values (Bayesian analysis) (Fig. 4). 


\section{Conflict of interest}

The Editor-in-Chief of Parasite is one of the authors of this manuscript. COPE (the Committee on Publication Ethics, http://publicationethics.org), to which Parasite adheres, advises special treatment in these cases. In this case, the final stage of the peer review process was handled by an Invited Editor, Jérôme Depaquit.

Acknowledgements. This study was supported by grants from several Interdisciplinary Programs of MNHN (ATM-Barcode, ATM-Microorganismes, ATM-Génomique et Collections, ATMCycles Biologiques), the Program "Bibliothèque du Vivant", Agence Universitaire de la Francophonie, and grants from the Japan Society for the Promotion of Science (Research Grant No. 26440216).

\section{References}

1. Adl SM, Habura A, Eglit Y. 2014. Amplification primers of SSU rDNA for soil protists. Soil Biology and Biochemistry, 69, 328-342.

2. Castresana J. 2000. Selection of conserved blocks from multiple alignments for their use in phylogenetic analysis. Molecular Biology and Evolution, 17, 540-552.

3. Chantangsi C, Lynn DH, Rueckert S, Prokopowicz AJ, Panha S, Leander BS. 2013. Fusiforma themisticola n. gen., n. sp., a new genus and species of apostome ciliate infecting the hyperiid amphipod Themisto libellula in the Canadian Beaufort Sea (Arctic Ocean), and establishment of the Pseudocolliniidae (Ciliophora, Apostomatia). Protist, 164(6), 793-810.

4. Chatton E, Lwoff A. 1935. Les Ciliés Apostomes. Morphologie, cytologie, éthologie, évolution, systématique. Première partie. Aperçu historique et général. Étude monographique des genres et des espèces. Archives de Zoologie Expérimentale et Générale, 77, 1-453.

5. Clamp JC, Bradbury PC, Strüder-Kypre MC, Lynn DH. 2008. Phylogenetic position of the apostome ciliates (Phylum Ciliophora, Subclass Apostomatia) tested using small subunit rRNA gene sequence. Denisia, 23, 395-402.

6. Clarke MR. 1970. Growth and development of Spirula spirula. Journal of the Marine Biological Association of the United Kingdom, 50(01), 53-64.

7. Collin B. 1915. A propos de Chromidina elegans (Foettinger). Comptes rendus de l'Académie des Sciences, 160, 406-408.

8. Darriba D, Taboada GL, Doallo R, Posada D. 2012. jModelTest 2: more models, new heuristics and parallel computing. Nature Methods, 9(8), 772.

9. Dellinger M, Labat A, Perrouault L, Grellier P. 2014. Haplomyxa saranae gen. nov. et sp. nov., a new naked freshwater foraminifer. Protist, 165(3), 317-329.

10. Dobell CC. 1909. Some observations on the infusoria parasitic in Cephalopoda. Journal of Microscopical Science, 53, 183-199.

11. Foettinger A. 1881. Recherches sur quelques Infusoires nouveaux parasites des Céphalopodes. Archives de Biologie, 2, 345-378.

12. Furuya H. 1999. Fourteen new species of dicyemid mesozoans from six Japanese cephalopods, with comments on host specificity. Species Diversity, 4, 257-319.
13. Furuya H, Ota M, Kimura R, Tsuneki K. 2004. Renal organs of cephalopods: a habitat for dicyemids and chromidinids. Journal of Morphology, 262(2), 629-643.

14. Gómez-Gutiérrez J, Strüder-Kypke MC, Lynn DH, Shaw TC, Aguilar-Mendez MJ, Lopez-Cortes A, Martinez-Gomez S, Robinson CJ. 2012. Pseudocollinia brintoni gen. nov., sp. nov. (Apostomatida: Colliniidae), a parasitoid ciliate infecting the euphausiid Nyctiphanes simplex. Diseases of Aquatic Organisms, 99(1), 57-78.

15. Gonder R. 1905. Beiträge zur Kenntnis der Kernverhältnisse bei den in Cephalopoden schmarotzenden Infusorien. Archiv für Protistenkunde, 5, 240-262.

16. Hall TA. 1999. BioEdit: a user-friendly biological sequence alignment editor and analysis program for Windows 95/98/NT. Nucleic Acids Symposium, 41, 95-98.

17. Hochberg FG. 1971. Some aspects of the biology of cephalopod kidney parasites. Ph.D. Dissertation, University of California, Santa Barbara.

18. Hochberg FG. 1982. The 'kidneys' of cephalopods: a unique habitat for parasites. Malacologia, 23, 121-134.

19. Hochberg FG. 1983. The parasite of cephalopods: a review. Memoirs of the National Museum of Victoria, Melbourne, 44, 109-145.

20. Hochberg FG. 1990. Diseases caused by protistans and mesozoans, in Diseases of Marine Animals, Vol. III, Kinne O, Editor. Biologische Anstalt Helgoland: Hamburg, Germany. p. 47-227.

21. ICZN. 1999. International Code of Zoological Nomenclature. The International Trust for Zoological Nomenclature: London, http://www.nhm.ac.uk/hosted-sites/iczn/code/ accessed on 22nd April 2016.

22. Jepps MW. 1931. Appendix: on a parasitic ciliate from Spirula. Danish Dana Expeditions, 8, 35-36.

23. Jereb P, Roper CFE. 2005. Cephalopods of the world. An annotated and illustrated catalogue of cephalopod species known to date. Chambered nautiluses and sepioids (Nautilidae, Sepiidae, Sepiolidae, Sepiadariidae, Idiosepiidae and Spirulidae), No. 4, Vol. 1. FAO: Rome. p. 262, 9 colour plates., Purposes. FSCfF, Ed.

24. Katoh K, Standley DM. 2013. MAFFT multiple sequence alignment software version 7: improvements in performance and usability. Molecular Biology and Evolution, 30(4), 772-780.

25. Landers SC. 2010. The fine structure of the tropho-tromont of the parasitic apostome Chromidina (Ciliophora, Apostomatida). Protistology, 6(4), 271-279.

26. Lara E, Berney C, Ekelund F, Harms H, Chatzinotas A. 2007. Molecular comparison of cultivable protozoa from a pristine and a polycyclic aromatic hydrocarbon polluted site. Soil Biology and Biochemistry, 39(1), 139-148.

27. Lynn DH, Gómez-Gutiérrez J, Strüder-Kypke MC, Shaw CT. 2014. Ciliate species diversity and host-parasitoid codiversification in Pseudocollinia infecting krill, with description of Pseudocollinia similis sp. nov. Diseases of Aquatic Organisms, 112(2), 89-102.

28. Nei M, Kumar S. 2000. Molecular evolution and phylogenetics. Oxford University Press: New York.

29. Nouvel H. 1945. Les Dicyémides de quelques céphalopodes des côtes françaises avec indication de la présence de Chromidinidés. Bulletin de l'Institut Océanographique: Monaco. p. 887. 
30. Ohtsuka S, Suzaki T, Kanazawa A, Ando M. 2015. Biology of symbiotic Apostome Ciliates: their diversity and importance in the aquatic ecosystems, in Marine Protists, Diversity and Dynamics. Springer: Japan. p. 441-463.

31. Romdhane MS. 1998. La pêche artisanale en Tunisie. Évolution des techniques ancestrales. Mélanges de l'École française de Rome. Antiquité, 110(1), 61-80.

32. Ronquist F, Teslenko M, van der Mark P, Ayres DL, Darling A, Hohna S, Larget B, Liu L, Suchard MA, Huelsenbeck JP. 2012.
MrBayes 3.2: efficient Bayesian phylogenetic inference and model choice across a large model space. Systematic Biology, 61(3), 539-542.

33. Tamura K, Stecher G, Peterson D, Filipski A, Kumar S. 2013. MEGA6: Molecular Evolutionary Genetics Analysis version 6.0. Molecular Biology and Evolution, 30(12), 2725-2729.

34. Wermel EM. 1928. Untersuchungen liber Chromidina elegans (Foell.) Gond. Archiv für Protistenkunde, 64, 419-445.

Cite this article as: Souidenne D, Florent I, Dellinger M, Justine JL, Romdhane MS, Furuya H \& Grellier P: Diversity of apostome ciliates, Chromidina spp. (Oligohymenophorea, Opalinopsidae), parasites of cephalopods of the Mediterranean Sea. Parasite, $2016,23,33$.

\section{- PARASTE}

An international open-access, peer-reviewed, online journal publishing high quality papers on all aspects of human and animal parasitology

Reviews, articles and short notes may be submitted. Fields include, but are not limited to: general, medical and veterinary parasitology; morphology, including ultrastructure; parasite systematics, including entomology, acarology, helminthology and protistology, and molecular analyses; molecular biology and biochemistry; immunology of parasitic diseases; host-parasite relationships; ecology and life history of parasites; epidemiology; therapeutics; new diagnostic tools.

All papers in Parasite are published in English. Manuscripts should have a broad interest and must not have been published or submitted elsewhere. No limit is imposed on the length of manuscripts.

Parasite (open-access) continues Parasite (print and online editions, 1994-2012) and Annales de Parasitologie Humaine et Comparée (1923-1993) and is the official journal of the Société Française de Parasitologie. 